\title{
A Preliminary Study for the Application of ISSR Markers to Discriminate Honey Bee (Apis mellifera L.) Populations in Turkey
}

\author{
Okan Can Arslan ${ }^{1, *}$ (]) \\ ${ }^{1}$ Middle East Technical University, Biology Department, Ankara, Turkey
}

\section{Article History}

Received 12 November 2020

Accepted 27 December 2020

First Online 28 December 2020

\section{*Corresponding Author \\ Tel.: +905358391144 \\ E-mail: okancanarslan@gmail.com}

\section{Keywords}

Inter simple sequence repeats

Genetic diversity

Subspecies distinction

\begin{abstract}
Potential of Inter Simple Sequence Repeats (ISSR) markers in analyzing and discriminating of Turkish honeybee populations was assessed in this study. Genomic DNA samples of workers belonging to four subspecies and two ecotypes of honey bees were amplified by PCR using 5 microsatellite primers. Principal component and population structure analyses showed that ISSR method successfully defined and discriminated four distinct Turkish honeybee subspecies while the two ecotypes of Anatoliaca subspecies were not distinctively separated from each other. This study showed that ISSR markers can be a simple and low-cost alternative with high resolution compared to other markers such as microsatellite and RAPD, in analyzing the genetic variations in Turkish honey bee subspecies.
\end{abstract}

\section{Introduction}

Anatolia's diverse climatic and geologic structure and its location as a bridge between Europe, Asia, and Africa led a considerable honey bee biodiversity in this region represented by five subspecies: $A$. $m$. caucasica at black sea region and northeastern Anatolia, A. m. carnica at Thrace region of north western Anatolia, $A$. $m$. anatoliaca, at western and central Anatolia, A. m. meda at southeastern Anatolia, and A. m. syriaca at Syria border region of southeastern Anatolia, (Ruttner, 1988; Kandemir, Kence, \& Kence, 2000; 2005)

Honeybee diversity in Turkey was extensively studied using allozyme polymorphism, mitochondrial DNA, RAPD and microsatellite markers (Smith, Slaymaker, Palmer, \& Kaftanoglu, 1997; Palmer, Smith, \& Kaftanoglu, 2000; Bodur, Kence, \& Kence, 2007; Tunca \& Kence, 2011; Karabağ, Tunca, Sevim, \& Doğaroğlu,
2020). Inter-SSR markers is based on amplification of genomic DNA segments flanked by the inversely oriented and closely spaced within microsatellite loci using microsatellite core unit bearing oligonucleotide primers. It combines the elements of microsatellite and RAPD methods ( $\mathrm{Wu}$, Jones, Danneberger, \& Scolnik, 1994). ISSR has fewer time and material cost compared to microsatellite analysis as it does not require designing specific primers for the taxon to be analyzed (Zietkiewicz, Rafalski, \& Labuda, 1994). It also produces more polymorphism compared to RAPD (Gupta, Chyi, Romerao-Severson, \& Owen, 1994) ISSR was previously used to analyze the genetic differences in honeybee populations of Saudi Arabia (Al Otaibi, 2008) and Lithuania (Čeksteryte, Paplauskiene, Tamasauskiene, Pasakinskiene, \& Mazeikiene, 2012). The aim of the study is to assess the utility of ISSR markers to discriminate some honeybee populations of different 
subspecies and regions in Turkey.

\section{Materials and Methods}

Worker honeybees were sampled from hives of pure line native subspecies maintained in the common garden of METU Biology Department. Subspecies used in this study are: A.m. caucasica from Artvin province, A.m. syriaca from Hatay, A.m. carnica from Kırklareli and, Yığılca and Muğla ecotypes of A.m. anatoliaca. Head and thorax parts honeybee samples which were frozen at $-80 \circ \mathrm{C}$ were dissected out and homogenized in ice cold TE buffer. DNA extraction from the homogenates were performed using Fermentas DNA isolation kit according to manufacturer's instructions. DNA concentration and quality in samples were determined by Nanodrop 2000c spectrometer. Five of SSR primers belonging to a primer set prepared by Biotechnology Laboratory of University of British Columbia (Vancouver, Canada) were used in PCR amplification (Table 1). ISSR-PCRs were carried out in a Techne TC-5000 gradient thermal cycler and reaction mixtures were prepared in a total volume of $15 \mu \mathrm{L}$ each containing 1X PCR buffer (10 mM Tris- $\mathrm{HCl} \mathrm{pH} \mathrm{8.8,} 50 \mathrm{mM}$ $\mathrm{KCl}$ and $0.1 \%$ Triton X-100), $2 \mathrm{mM}$ of $\mathrm{MgCl}_{2}, 200 \mu \mathrm{M}$ of each of the dNTPs (dATP, dCTP, dGTP and dTTP), 0.25 $\mu \mathrm{M}$ of primer,0.5UT a qDNA polymerase (MBI, Fermentas) and $25 \mathrm{ng}$ of template DNA. Time and thermal profile of the PCR were as follows 2 min of initial denaturation at $94^{\circ} \mathrm{C}$, followed by 34 cycles; each consisting of a denaturation segment of $20 \mathrm{~s}$ at $94^{\circ} \mathrm{C}$, an annealing segment of $1 \mathrm{~min}$ at 54 to $56^{\circ} \mathrm{C}$ depending on the primer and an extension segment of $2 \mathrm{~min}$ at $72^{\circ} \mathrm{C}$. PCR was terminated with a final extension period of 5 $\min$ at $72^{\circ} \mathrm{C}$, and products were electrophoresed in $1.5 \%$ agarose gels along with one lane of size markers. Fragments were visualized on a UV transilluminator following staining with $0.4 \mu \mathrm{g} / \mathrm{mL}$ ethidium bromide solution (Figure 1).

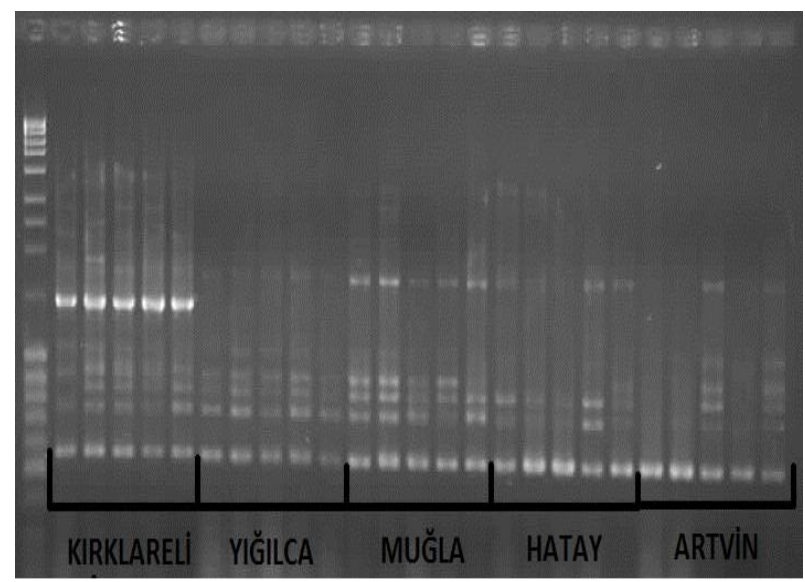

Figure 1. An example of PCR profiles of honey bees belonging to five populations.
Screening 150 honeybee samples with 5 SSR primers produced at 19 gel positions (loci). Each locus was treated as a separate character, and the presence or the absence of a PCR product at each position was scored as 1 and 0 respectively. Principal Component analysis (PCA) was performed by NTSYS-pc program to define and discriminate study samples. Population structure and possible hybridizations between samples were analyzed by Structure Software. Other genetic variation parameters were calculated by PopGene Program

\section{Results}

A total of 150 bee samples from 5 populations were screened with 5 primers in this study. In terms of genetic variation parameters (Table 1) populations showed a gradual increase with Artvin (caucasica) has the lowest while Kırklareli (carnica) had the highest scores (Table 2). The two- and three-dimensional graphics (Figures 2 and 3) of PCA analysis shows that the sample groups of four subspecies involved in our study, clearly separate from each other while Yığılca and Muğla ecotypes of anatoliaca subspecies are generally grouped together. Population structure analysis (Figure 4) also show distinctive patterns for each subspecies although there is some degree of introgression between the populations. Yığılca and Muğla ecotypes of anatoliaca honeybee also show remarkably similar structural patterns.

\section{Discussion and Conclusion}

Studies showed evidence of genetic homogenization and loss of genetic diversity in some areas of Europe. Dall'Olio, Marino, Lodesani, and Moritz (2007) reported high level of homogenization and decrease in previously reported genetic diversity in Italian peninsula. Canovas, de la Rua, Serrano, and Galian (2011) also found an increased level of homogenization in Iberian honeybee (A. m. iberiensis) colonies from Spain. Bouga et al. (2005 a,b) observed no genetic distinction in terms of mitochondrial and allozyme data between native adami, macedonica and cecropia subspecies in Greece. The main reasons for this phenomenon are migratory beekeeping and replacing the queens of native honeybee colonies with commercial breeds of other subspecies (especially caucasica in Turkey) and their hybrids (Kükrer, 2013). Therefore, a simple, fast and cost-effective method is needed for genetic screening for native honeybee subspecies to detect possible homogenization and introgression events.

ISSR markers appeared to be an effective tool in analyzing and discriminating different honeybee populations and subspecies. Population structure analysis show distinct patterns between subspecies with some degree of hybridization. This is consistent with 
Table 1. Primer sequences and numbers of gel positions scored.

\begin{tabular}{llccc}
\hline Primers & Sequences 5' $\rightarrow 3^{\prime}$ & $\begin{array}{c}\text { Total } \\
\text { Bands }\end{array}$ & $\begin{array}{c}\text { Polymorphic } \\
\text { bands }\end{array}$ & $\begin{array}{c}\text { Percentage of } \\
\text { polymorphic Bands }\end{array}$ \\
\hline UBC 818 & CAC ACA CAC ACA CAC AG & 3 & 2 & 66 \\
UBC 840 & CAC ACA CAC ACA CAC AG & 5 & 4 & 80 \\
UBC 847 & CAC ACA CAC ACA CAC ARC & 4 & 4 & 100 \\
UBC 856 & ACA CAC ACA CAC ACA CYA & 5 & 4 & 80 \\
UBC 899 & CAT GGT GTT GGT CAT TGT TCC & 2 & 2 & 100 \\
\hline
\end{tabular}

Table 2. Genetic variation and polymorphism in different indigenous honeybee populations from Turkey. NPL number of polymorphic loci, PPL percentage of polymorphic loci, $\mathrm{Na}$ observed number of alleles per locus, Ne effective number of alleles, $H$ Nei's gene diversity I Shannon's Information index.

\begin{tabular}{lllcccc}
\hline Populations & NPL & PPL & NA & NE & $\mathrm{H}$ & $\mathrm{I}$ \\
\hline Artvin & 10 & 50 & $1.500 \pm 0.513$ & $1.250 \pm 0.361$ & $0.146 \pm 0.196$ & $0.223 \pm 0.280$ \\
Hatay & 11 & 55 & $1.550 \pm 0.510$ & $1.268 \pm 0.358$ & $0.160 \pm 0.193$ & $0.246 \pm 0.275$ \\
Kırklareli & 12 & 60 & $1.600 \pm 0.502$ & $1.393 \pm 0.389$ & $0.228 \pm 0.207$ & $0.337 \pm 0.297$ \\
Muğla & 14 & 70 & $1.700 \pm 0.470$ & $1.422 \pm 0.372$ & $0.248 \pm 0.200$ & $0.370 \pm 0.283$ \\
Yı̆̆ııca & 17 & 85 & $1.850 \pm 0.366$ & $1.425 \pm 0.351$ & $0.257 \pm 0.178$ & $0.395 \pm 0.241$ \\
\hline
\end{tabular}

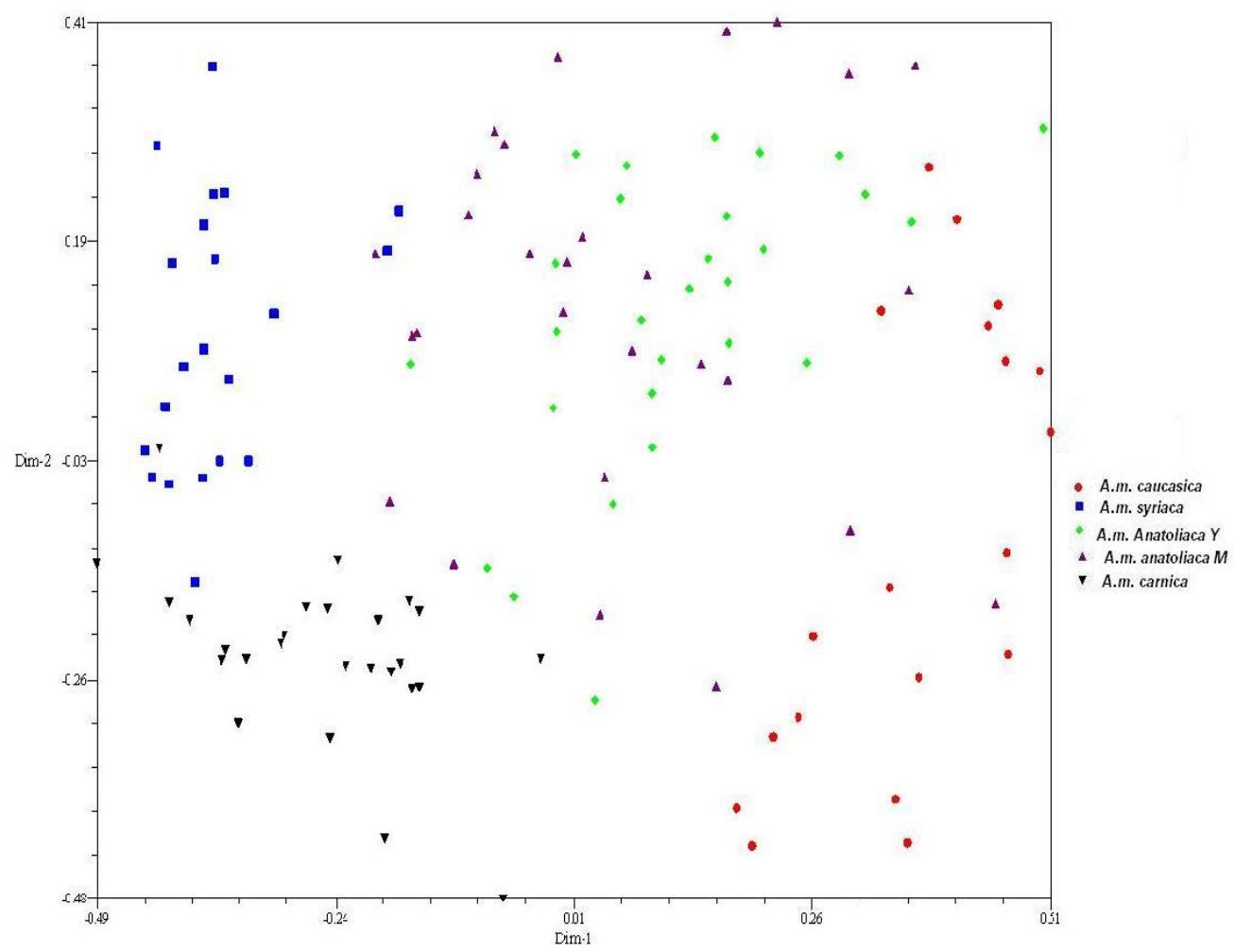

Figure 2. Two-dimensional principle coordinate analysis of 150 honey bees from 5 populations according to a distance matrix based on Jacard Index. 


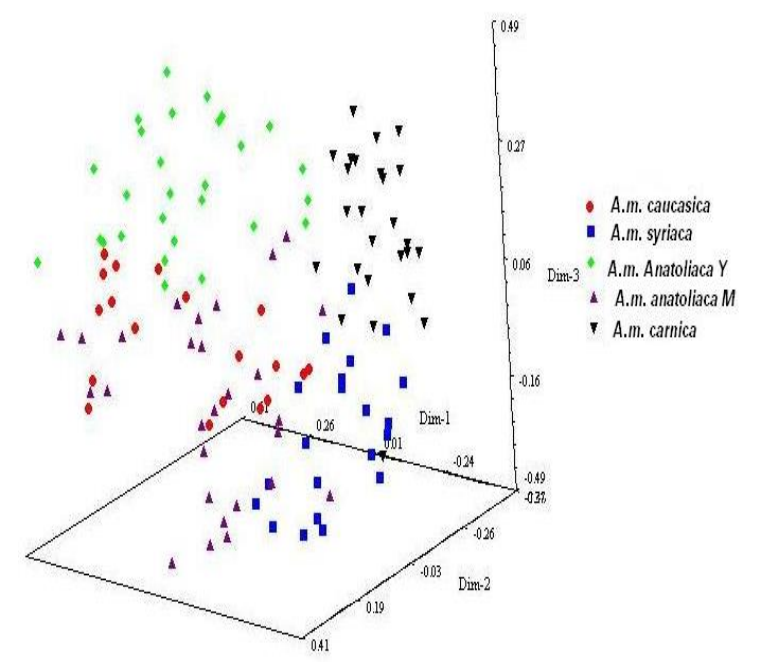

Figure 3: Three- dimensional principle coordinate analysis of 150 honey bees from 5 populations according to a distance matrix based on Jacard Index.

previous studies which showed that honeybee populations in different regions of Anatolia still retain their distinctive genetic structures despite hybridization caused by migratory beekeeping (Tunca, 2009, Kükrer, 2013). In addition to this, Yığılca and Muğla ecotypes of A. m. Anatoliaca subspecies are revealed to be genetically quite similar even though they are adapted to different ecological conditions. In conclusion, ISSR method proved itself to be a simple and low-cost method capable of identifying and discriminating honeybee subspecies and populations of Turkey.

\section{Acknowledgements}

Author thanks to Prof. Dr. Aykut KENCE (R.I. P.) and Assoc. Prof. Dr. Meral KENCE from METU for their guidance and, Assist. Prof. Dr. Mehmet Ali SÜDÜPAK from Yozgat Bozok University for providing the microsatellite primers for this study. Part of this study was presented as a poster in 2013 Apimondia International Congress, Kyiv-Ukraine.

\section{References}

Al-Otaibi, S.A. (2008). Genetic variability in mite-resistant honey bee using ISSR molecular markers. Arab Journal of Biotecnology, 11, 241-252.

Bodur, C., Kence, M., \& Kence, A. (2007). Genetic structure of honeybee, Apis mellifera L. (Hymenoptera: Apidae) populations of Turkey inferred from microsatellite analysis. Journal of Apicultural Research, 46(1), 50-56.

Bouga, M., Kilias, G., Harizanis, P.C., Papastiropoulos, V., \& Alahiotis, S. (2005a). Allozyme variability and phylogenetic relationships in honey bee (Hymenoptera: Apidae: A. mellifera) populations from Greece and Cyprus. Biochemical Genetics, 43, 471-484.

Bouga, M., Harizanis, P. C., Kilias, G., \& Alahiotis, S. (2005b). Genetic divergence and phylogenetic relationships of

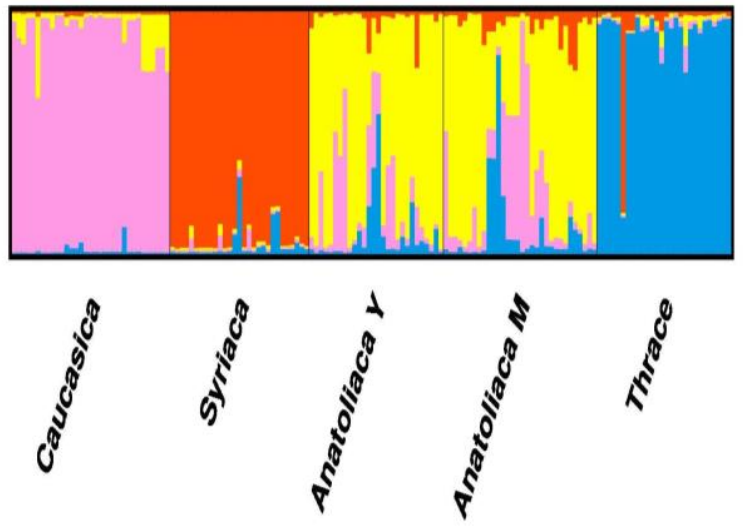

Figure 4: Structure analysis for five honey bee populations of Turkey.

honey bee Apis mellifera (Hymenoptera: Apidae) populations from Greece and Cyprus using PCR - RFLP analysis of three mtDNA segments. Apidologie, 36, 335344.

Cánovas, F., de la Rúa, P., Serrano, J., \& Galián, J. (2011). Microsatellite variability reveals beekeeping influences on Iberian honeybee populations. Apidologie, 42(3), 235-251.

Čeksteryte, V., Paplauskiene, V., Tamasauskiene, D., Pasakinskiene, I., \& Mazeikiene, I. (2012). Genetic characterization of Lithuanian honeybee lines based on ISSR polymorphism. Apidologie, 43, 652-662.

Dall'Olio, R., Marino, A., Lodesani, M., \& Moritz, R. F. (2007). Genetic characterization of Italian honeybees, Apis mellifera ligustica, based on microsatellite DNA polymorphisms. Apidologie, 38(2), 207-217.

Gupta, M., Chyi, Y.S., Romero-Severson, J., \& Owen, J.L. (1994). Amplification of DNA markers from evolutionarily diverse genomes using single primers of simplesequence repeats. Theoretical and applied genetics, 89(7-8), 998-1006.

Kandemir, I., Kence, M., \& Kence, A. (2000). Genetic and morphometric variation in honeybee (Apis mellifera L.) populations of Turkey. Apidologie, 31(3), 343-356.

Kandemir, İ., Kence, M., \& Kence, A. (2005). Morphometric and electrophoretic variation in different honeybee (Apis mellifera L.) populations. Turkish Journal of Veterinary and Animal Sciences, 29(3), 885-890.

Karabağ, K., Tunca, R. i., Sevim, E. T., \& Doğaroğlu, T. (2020). Current genetic status of honey bees in Anatolia in terms of thirty polymorphic microsatellite markers. Türkiye Entomoloji Dergisi, 44(3), 333-346.

Kükrer, M. (2013). Genetic diversity of honey bee populations in Turkey based on microsatellite markers: A comparison between migratory versus stationary apiaries and isolated regions versus regions open to migratory beekeeping (MSc dissertation). Middle East Technical University, Ankara, Turkey.

Palmer, M. R., Smith, D. R., \& Kaftanoglu, O. (2000). Turkish honeybees: genetic variation and evidence for a fourth lineage of Apis mellifera mtDNA. The Journal of Heredity, 


\section{$91,42-46$.}

Ruttner, F. (2013). Biogeography and taxonomy of honeybees. Springer Science \& Business Media.

Smith, D.R., Slaymaker, A., Palmer, M., \& Kaftanoglu, O. (1997) Turkish honeybees belong to the east Mediterranean lineage. Apidologie, 28, 269-274

Tunca, R.I., \& Kence, M. (2011). Genetic diversity of honey bee (Apis mellifera L.: Hymenoptera: Apidae) populations in Turkey revealed by RAPD markers. African Journal of Agricultural Research, 6(29), 6217-6225.

Tunca, R.I. (2009). Determination and Comparison of Genetic
Variation in Honeybee (Apis mellifera L.) Populations of Turkey by Random Amplified Polymorphic DNA and Microsatellite Analyses (PhD dissertation). Middle East Technical University, Ankara, Turkey.

Wu, K.S., Jones, R., Danneberger, L., \& Scolnik, P.A. (1994). Detection of microsatellite polymorphisms without cloning. Nucleic acids research, 22(15), 3257-3258.

Zietkiewicz, E., Rafalski, A., \& Labuda, D. (1994). Genome fingerprinting by simple sequence repeat (SSR)anchored polymerase chain reaction amplification. Genomics, 20(2), 176-183. 
